\title{
Evaluation and analysis of freshwater from atmospheric moisture as byproduct of air-cooling units in Oman
}

\author{
Iessa Sabble Moosa ${ }^{1,}$, Hussien A. Kazem ${ }^{2}$, Humaid Al-Badi ${ }^{3}$, and Ahmed Said Al-Hashimi ${ }^{4}$ \\ ${ }^{1}$ Research cooperator with Public Authority for Water, Al-Buraimi Province, P.C. 512, Oman \\ ${ }^{2}$ Faculty of Engineering, Sohar University, Sohar, P.C. 311, Oman \\ 3 Directorate General of Meteorology, Muscat, Oman \\ ${ }^{4}$ Electrical Engineer, Technical College, Al-Musannah, Oman
}

Received: 5 April 2021 / Accepted: 29 April 2021

\begin{abstract}
Providing water for different uses to maintain life activities is a target for many nations. So, managing the existing water resources and finding new water sources are essential for any nation's water security. In the present article, 4 years daily meteorological data, such as relative humidity, air-temperatures, and global solar irradiation were analyzed to support the explanation of high-level humidity in the coastal plains of Oman, and the effect of that on water production from atmospheric moisture. What applies to the coast of Oman is also valid on the coasts of the Gulf Cooperation Council. It is found that the annual mean value of the RH\% along the Omani coast is about $68 \%$ for 4 years (2016-2019). Also, the study of the air-temperatures data revealed very clear decreasing in the direction toward the south of Oman due to the geographical diversity. It is found that the lowest annual air- temperatures were in the far south city, Dhalkut (about Max., Mean, Min., 25, $22,20^{\circ} \mathrm{C}$, respectively). Three years (2017-2019) of global solar irradiation data of Muscat International Airport showed a maximum value of around $7300 \mathrm{~W} / \mathrm{m}^{2}$ in June. In addition, a part of the research work was to investigate the byproduct drain-water that comes out from big air-cooling units with a rate power of about $21.73 \mathrm{~kW}$ each. The result indicated that a Net Annual Rate of freshwater of about $1892 \mathrm{~m}^{3} /$ year can be accumulated from one supermarket air-cooling units nearby the line coast of Oman. Also, the chemical, physical, and bacterial tests were carried out to find some parameters, such as TDS, EC, pH, and bacterial contamination. The results were encouraging towards the purity of the byproduct water, and the existing bacteria could be killed by solar energy.
\end{abstract}

\section{Introduction}

Security of water is one of the difficult challenges that many countries face to maintain their life and development plans, especially those that suffer from water scarcity. Accordingly, the strict policy of managing water resources and the communities' awareness of the importance of this problem is the basis of the plan to control the water resources of any country $[1,2]$. Most of the countries in the Middle East, especially the Gulf Cooperation Council (GCC), need exceptional measures to allocate their water resources rationally to ensure running their life and development plans properly. Oman is among the GCC countries faces this strategic issue because of its location in a semi-desert zone with limited water resources [3,4]. Oman area is about

\footnotetext{
* e-mail: dr.iessa89@gmail.com
}

$3.1 \times 10^{5} \mathrm{~km}^{2}(\sim 83 \%$ desert, $\sim 14 \%$ mountains, and $\sim 3 \%$ coastal plains) [5]. Almost full information about food and water security of Oman up to 2030 has been reported in the preceding reference. Also, it is found that desalinated water covers more than $86 \%$ of required drinking water in Oman, and about $14 \%$ is provided by underground water and distillation seawater. Geographical Information Systems (GIS) were employed to assess the water security of Oman across its Provinces to draw a clear map for water distribution [6]. Water resources of Oman are as follows; underground water, rainwater that collects in dams, desalination of seawater, distillation seawater, and fog harvesting water [7].

Distillation of seawater by solar energy is one of Oman concerns to address the problem of water deficit, especially drinking water. Details about this subject have been investigated by many researchers in this field [8-10]. Solar distillation looks very promising to produce pure water 
because of Oman and other GCC countries characterized by high solar intensity and sunny shine days a year [11]. This technique does not need highly complex technology for water production from seawater or brackish water, and productive because of much plentiful solar energy in the GCC territories.

Recently, Moosa et al. have reported that freshwater can be collected directly from air-cooling units as a byproduct $[12,13]$. They experimentally showed that the released drain-water comes out from the cooling airconditioner is almost distilled water with very low electrical conductivity, $\mathrm{pH}$ of about 7 , and high quantities. This work can be developed for large scale for collecting vast quantities of byproduct freshwater, which usually goes to the sewage system or evaporates. This idea is not previously published and probably useful in filling part of the water deficit in countries that have high and moderate relative humidity in their different regions, such as Oman and the other GCC countries. Oman has a coastal line of about $3165 \mathrm{~km}$ long with high relative humidity, so that the idea of collecting the byproduct water from cooling systems looks to be very beneficial to augment water security if it is exploited on a national level.

The present study aims to evaluate the byproduct drain-water that is released from the air-cooling system in humid locations in Oman to use it in numerous domestic applications. A large-scale application has been applied in Al-Musannah city, and the collected freshwater was tested and analyzed. Moreover, physical test, chemical analysis, and bacterial test of the collected water have been conducted. Also, meteorological data in Oman has been conducted for four-year period and analysis concerning the plan of applying the idea in different locations is presented.

The study contains after the introduction, metrological data in Oman to evaluate the relative humidity and airtemperature in different locations, and global irradiation of Muscat International Airport. In another part, the drainwater collection from air-cooling units was described and evaluated. Furthermore, the chemical analysis, physical test, and the bacterial test was presented. Finally, the study discussed and concluded the achievements.

\section{Meteorological data in Oman}

Meteorological data were provided by the "Public Authority for Civil Aviation Directorate General of Meteorology" of Oman for some stations in the coastal plains. Another data about solar irradiation were also received from the same Directorate at Muscat International Airport, to support the research plan. The data include: - Max. Mean, and Min. of relative humidity $(\mathrm{RH} \%)$ and air-temperature $(\mathrm{Ta})\left({ }^{\circ} \mathrm{C}\right)$ for 4 years $2016-2019$.

- Solar irradiation (G) (W/ $\left.\mathrm{m}^{2}\right)$ for three years 2107,2018 , and 2019, Muscat International Airport station, Oman.

The meteorological data analysis is essential to perceive the factors affecting the amount of condensed water in any air-cooling systems, which can be used in different domestic applications. It is axiomatic that the amount of condensed water from the atmospheric moisture in any air-cooling system is directly proportional

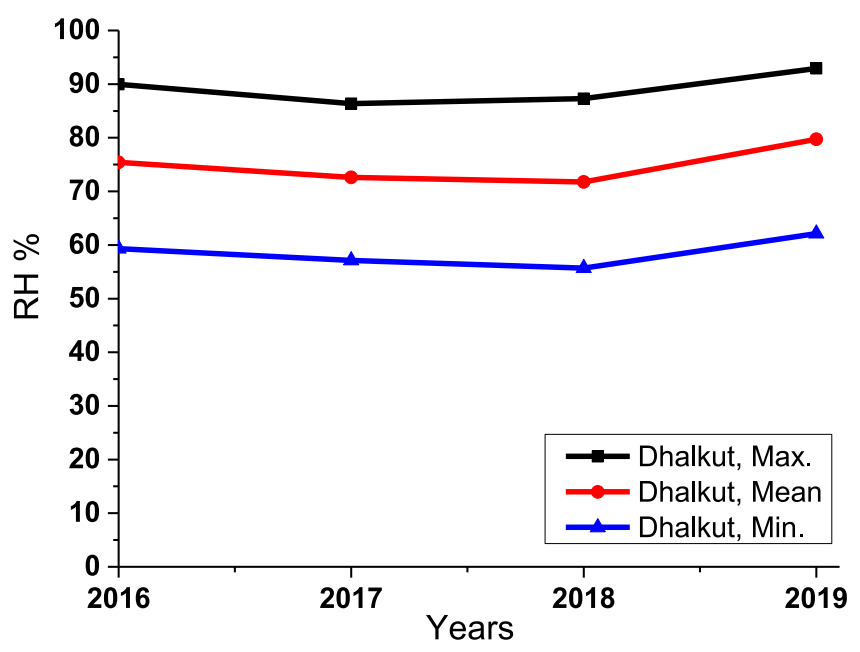

Fig. 1. Annual mean values for many years of RH\%, Dhalkut location, Oman.

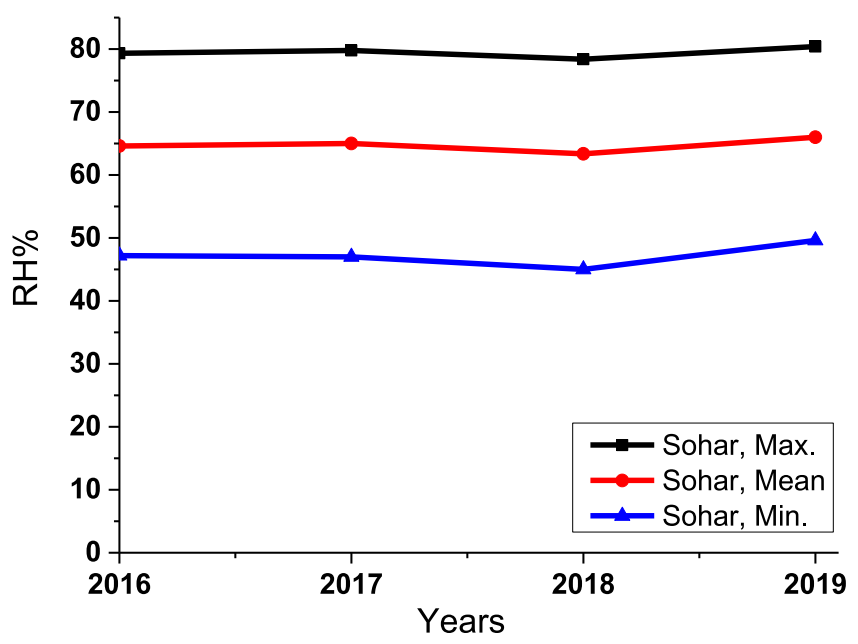

Fig. 2. Annual mean values of $\mathrm{RH} \%$ for many years, Sohar location, Oman.

to the increase in the (RH\%). Therefore, the annual mean values of RH\% (Max., Mean, and Min.) for 4 years (2016-2019) was plotted for Dhalkut and Sohar locations nearby the coastal line of Oman as shown in Figures 1 and 2. Figure 3 exposes the sites on the map of Oman as red spots to monitor various meteorological data. The green spots are the eight chosen locations to analysis their meteorological data related to the aim of the present article.

Also, the mean values of Max., Mean, and Min. of RH\% for the eight selected sites were graphed in Figure 4 for 4 years (2016-2019), to show the general variation during this long period. Also, annual values of air temperatures (Max., Mean, Min.) for the same cities above, for the years (2016-2109) were plotted as shown in Figures 5 and 6 to harmonize with the obtained curves of the $\mathrm{RH} \%$ shown in Figures 1 and 2.

In addition, the mean values of the RH\% (Max., Mean, and Min.) for the period (2016-2019) in many coastal locations that shown in Figure 3 were graphed together to see the general trend of the $\mathrm{RH} \%$ of these locations, as 


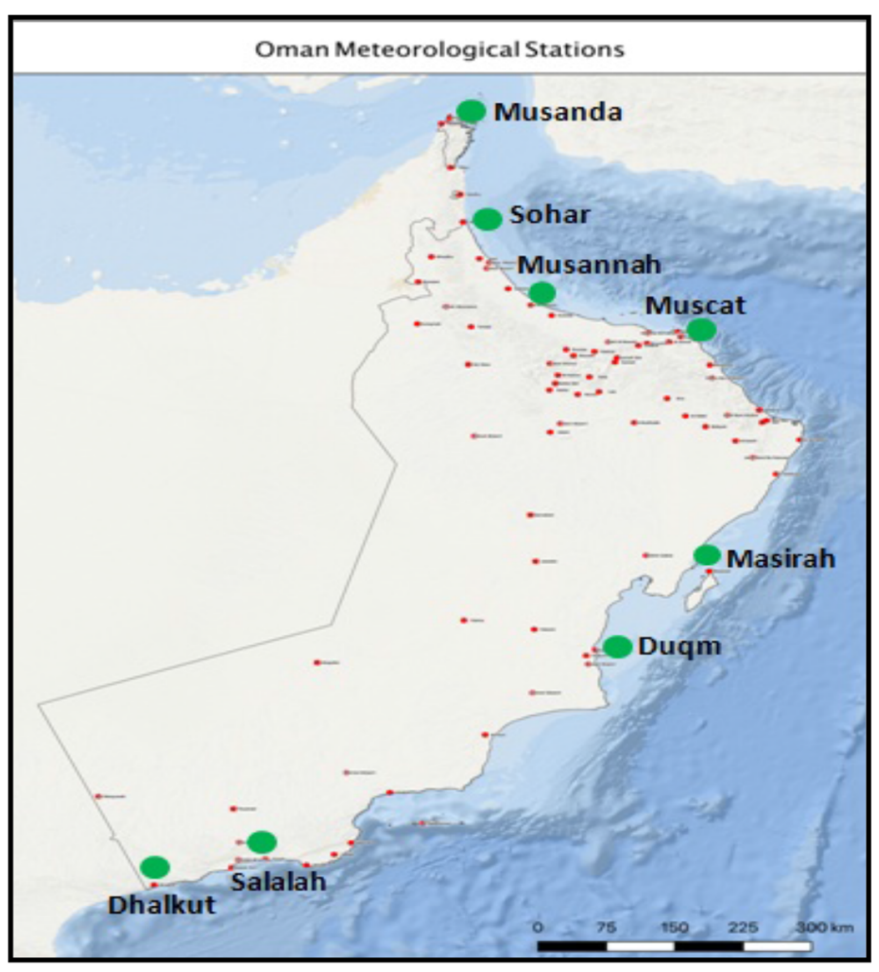

Fig. 3. Locations of Oman meteorological stations with red spots, green spots are the eight chosen to study locations.

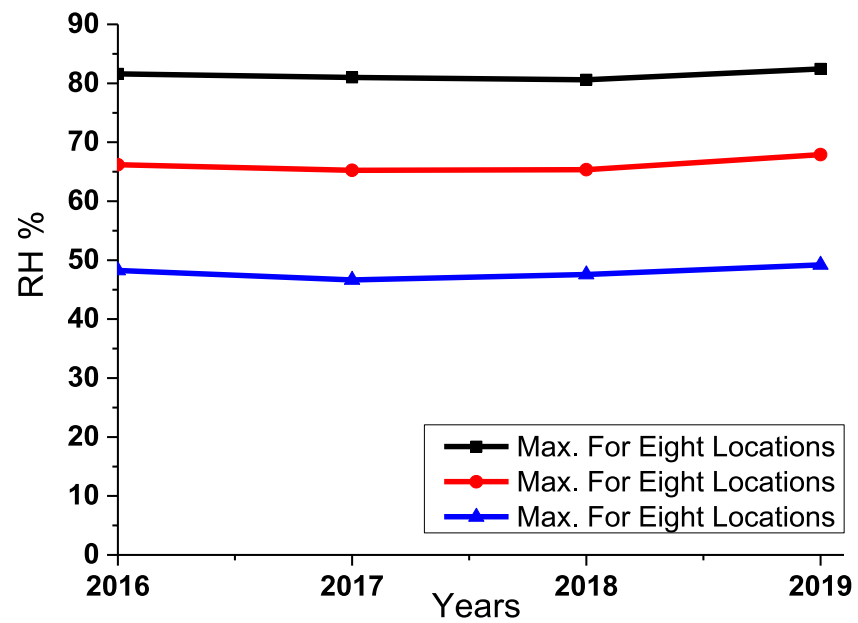

Fig. 4. The annual mean values of RH\% (Max., Mean, and Min.) of 4 years for the eight selected locations.

depicted in Figures 7 and 8 . Also, the Ta mean values of the same period above were plotted for the same locations as given in Figure 9.

The GCC states, including Oman, are characterized by coasts with high $\mathrm{RH} \%$ due to their geographical location, which also receives very high solar radiation intensity, as exposed in the global solar radiation distribution map [14].

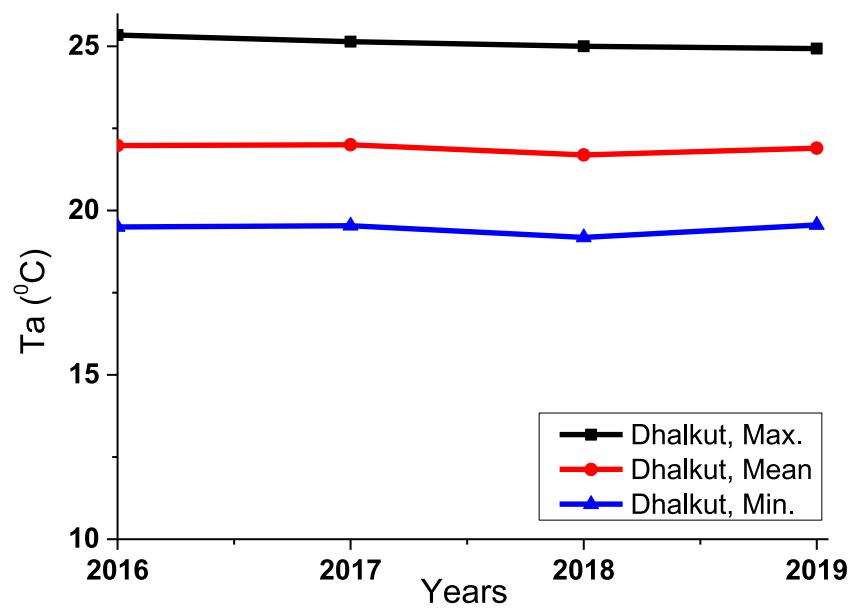

Fig. 5. Reveals annual mean values of air-temperatures (Max. Mean, and Min.) for many years, Dhalkut location, Oman.

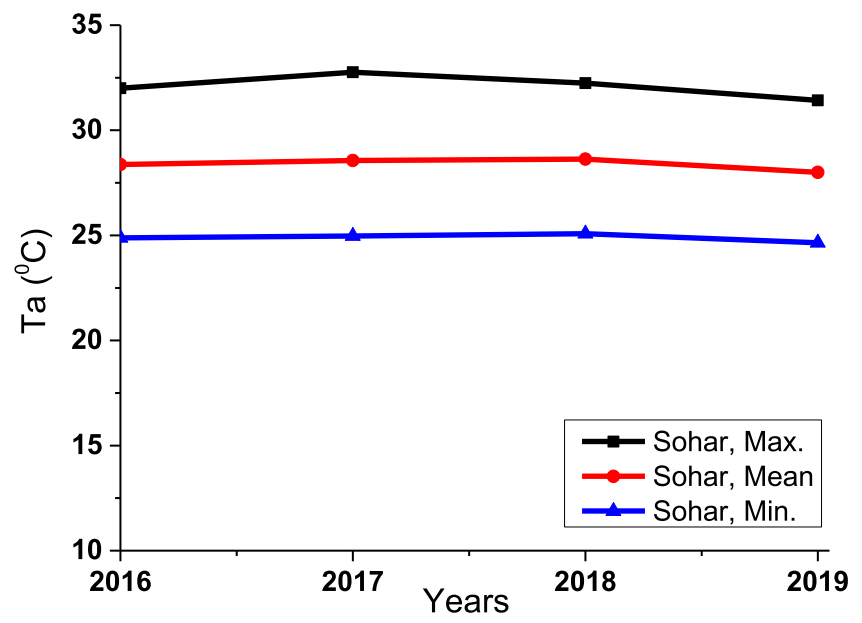

Fig. 6. Reveals annual mean values of air-temperatures (Max. Mean, and Min.) for many years, Sohar location, Oman.

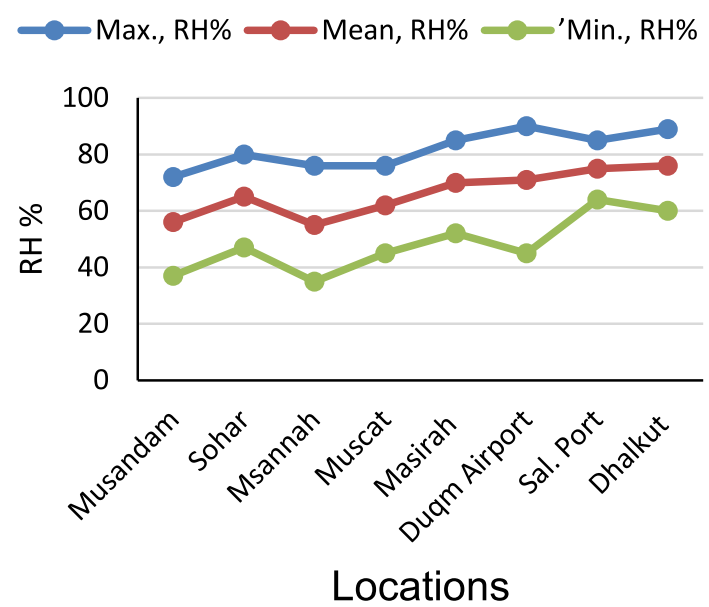

Fig. 7. Annual mean values of Max., Mean, and Min. of $\mathrm{RH} \%$ for 4 years (2016-2019), eight selected coastal locations, Oman. 
max., RH\% $\square$ Mean, $\mathrm{RH} \% \quad$ 'Min., RH\%

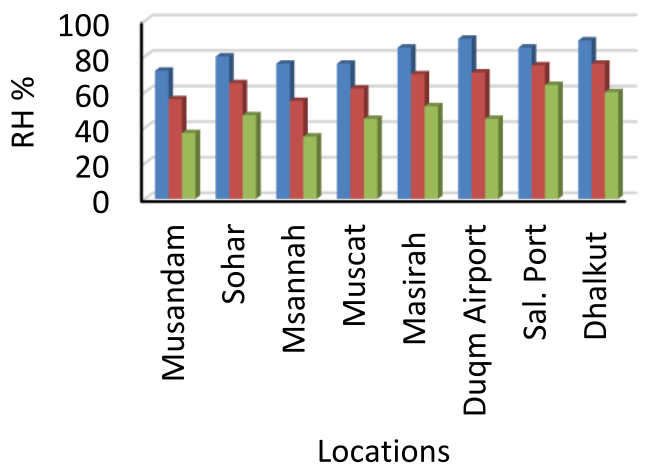

Fig. 8. RH\% (2016-2019) for the eight mentioned locations, Oman.

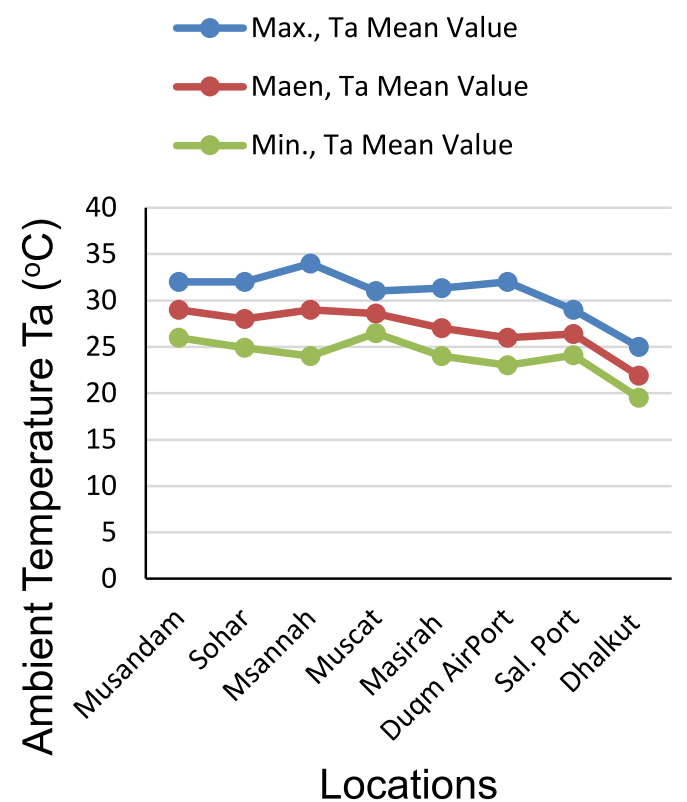

Fig. 9. Reveals the mean values of Ta for 4 years (2016-2019) in eight chosen coastal locations, Oman.

From providing meteorological data, it is necessary to have an idea about the values of annual $\mathrm{G}$ distribution in Oman, where Muscat International Airport was chosen as an example. Hence, the monthly mean values of three years (2017-2019) of G illustrated in Figure 10. Also, the data of Figure 10 shows bar graph to identify the general trend of this important factor on the values of the $\mathrm{RH} \%$ in general.

Also, the annual global mean values of G of Muscat International Airport for the 3 years (2017-2019) were plotted as shown in Figure 11, to have a general muse about the climate stability and the effect of this parameter on the $\mathrm{RH} \%$ data.

\section{Drain-water collection from air-cooling units}

The second part of the current work of research is to generalize the idea of gaining the advantage of the

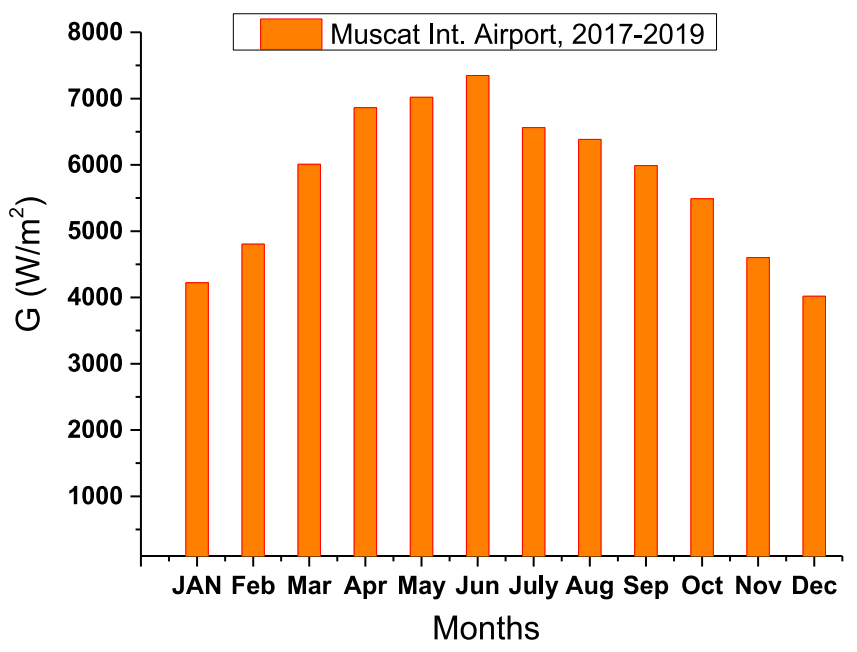

Fig. 10. Monthly G means values for three years, Muscat International Airport, Oman.

byproduct water that releases out of air-cooling units in humid areas. This subject has been widely investigated in small scale before [13]. Therefore, this study was investigating the idea on a large scale to motivate people and highlight the benefits of the byproduct water of airconditioning systems.

Drain-water from "Nesto Hypermarket", Al-Musannah city branch in Oman, North of Muscat by about $120 \mathrm{~km}$ was collected as a byproduct water from the air-cooling units of the market. The city is coastal, as shown in Figure 12, and the Hyper Market is about $5 \mathrm{~km}$ far from the coast of Al-Musannah.

This case is an attempt of large-scale water collection from supermarket cooling units.

The water collection system includes the following stuff:

- Cooling units of "Nesto Hypermarket" were exploited for water accumulation. Eight units were there, with a rate power of about $21.73 \mathrm{~kW}$ each. Table 1 indicates technical specifications of the used cooling units.

- Connection pipes.

- Two plastic containers with a capacity of 600 gallons each have been used.

Figure 13 shows pictures of the cooling units together with the plastic water containers in a ground hole. Many runs of filling the plastic containers by the air-cooling byproduct water were carried out in many days.

The dates of water collection, the quantity of gaining water, the conjugated mean values of $\mathrm{RH} \%$, and the air- temperatures were recorded as shown in Table 2.

The water quantity was converted into liter unit $(1$ Gallon $\approx 3.8 \mathrm{~L})$. The results were graphed in Figure 14 to give a general view about the byproduct water rate that can be gained from one air-cooling unit of the supermarket in different values of $\mathrm{RH} \%$. 


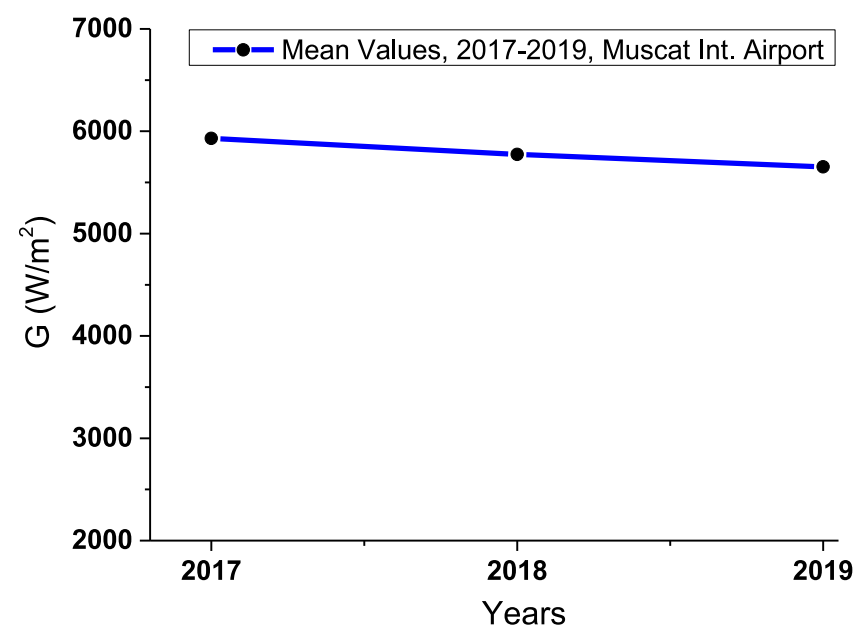

Fig. 11. Annual global means of G vs. 3 years (2017-2019), Muscat International Airport, Oman.

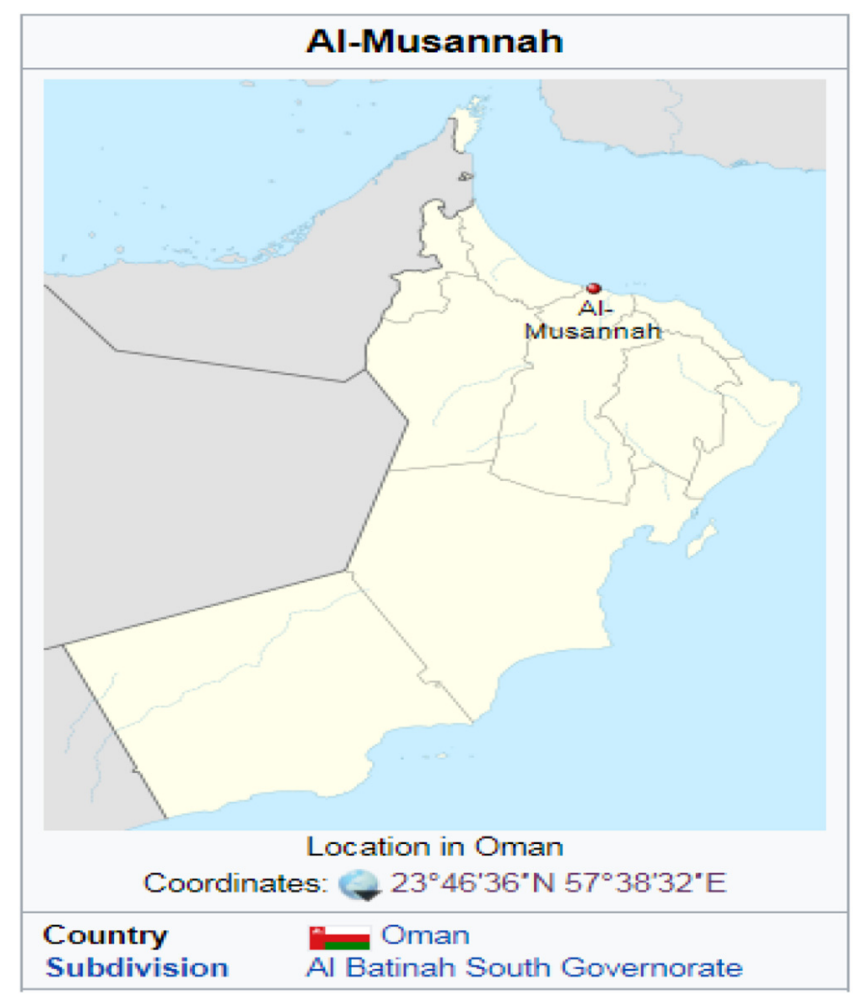

Fig. 12. Al-Musannah location on Oman map (https://en. wikipedia.org/wiki/Al-Musannah), 01/10/2020.

\section{Chemical analysis, physical test, and bacterial test}

Chemical analysis and physical test were conducted in the Lab. of Mahadha Water Natural Factory, Al-Buraimi Provence-Oman, to find some parameters of the collected water. Meanwhile, a bacterial test was also carried out to give an idea of bacterial contamination.
Table 1. Three-phase air-conditioning specifications, Type Carrier, Made in Saudi Arabia Kingdom.

\begin{tabular}{ll}
\hline Mode & 50TJM-28A9 \\
\hline Power supply voltage & $400 \pm 40 \mathrm{~V}$ \\
Frequency & $50 \mathrm{~Hz}$ \\
Minimum current & $54.3 \mathrm{~A}$ \\
Rate power input & $21.73 \mathrm{~kW}$ \\
Rate cooling capacity & $254537 \mathrm{Btu} / \mathrm{hr}$ \\
Rated current & $41.6 \mathrm{~A}$ \\
\hline
\end{tabular}

Three samples of water were collected directly from the drain-water source that connected to the plastic tanks for chemical and physical tests. Table 3 includes some chemical and physical characterization of the gained water from the used air-cooling units.

Six samples were also collected using in advanced sterilized glass bottles prior to the bacterial test and solar disinfection. These samples must be taken $24 \mathrm{~h}$ before the bacterial test according to the adopted procedure. Three of them were tested directly, while the other three were tested after solar disinfection. Table 4 includes the results of bacterial test before and after the solar disinfection. Furthermore, after 2 weeks, the bacterial test was repeated on the three samples that were already disinfected by solar energy to be sure that there are no bacteria bred back.

\section{Result and discussion}

\subsection{Evaluation of meteorological data}

Water condensed from the atmosphere by any method of cooling depends on the relative humidity, and the last depends typically on G level and Ta. Logically, the higher the relative humidity at the dew water temperature, the greater quantity of condensate water. That is, the amount of gaining water from air-cooling systems is directly proportional to the $\mathrm{RH} \%$ at the dew temperature of the water. Also, another important parameter to increase the gained water from cooling units is the temperature setting. In general, the lowest temperature setting, the higher collected drain-water at the same level of humidity.

It is obvious to conclude from Figures 1 and 2 that the values of the $\mathrm{RH} \%$ of Dhalkut are much higher than that of Sohar. The lines of the two cases are nearly parallel to each other for 2016, 2017, and 2018, whilst in 2019, there are little increases in the three values (Max., Mean, Min.) of the $\mathrm{RH} \%$ for both locations. This result can be explained basis on of decreasing the annual mean values of the Ta in 2019, as shown in Figures 5 and 6. Because, generally, the $\mathrm{RH} \%$ is inversely proportional to the Ta. Figure 3 reveals the coastal chosen locations to recognize them on the map of Oman. From Figure 4, it can be seen that the trend of the three curves is nearly the same, and reflects that the values of Max., Mean, and Min. are high for an extended period along the coast of Oman. This remarkable fact is very encouraging to go ahead forgetting the full benefit of high humidity zones for freshwater production, mainly to collect the byproduct water of the air-cooling units. 


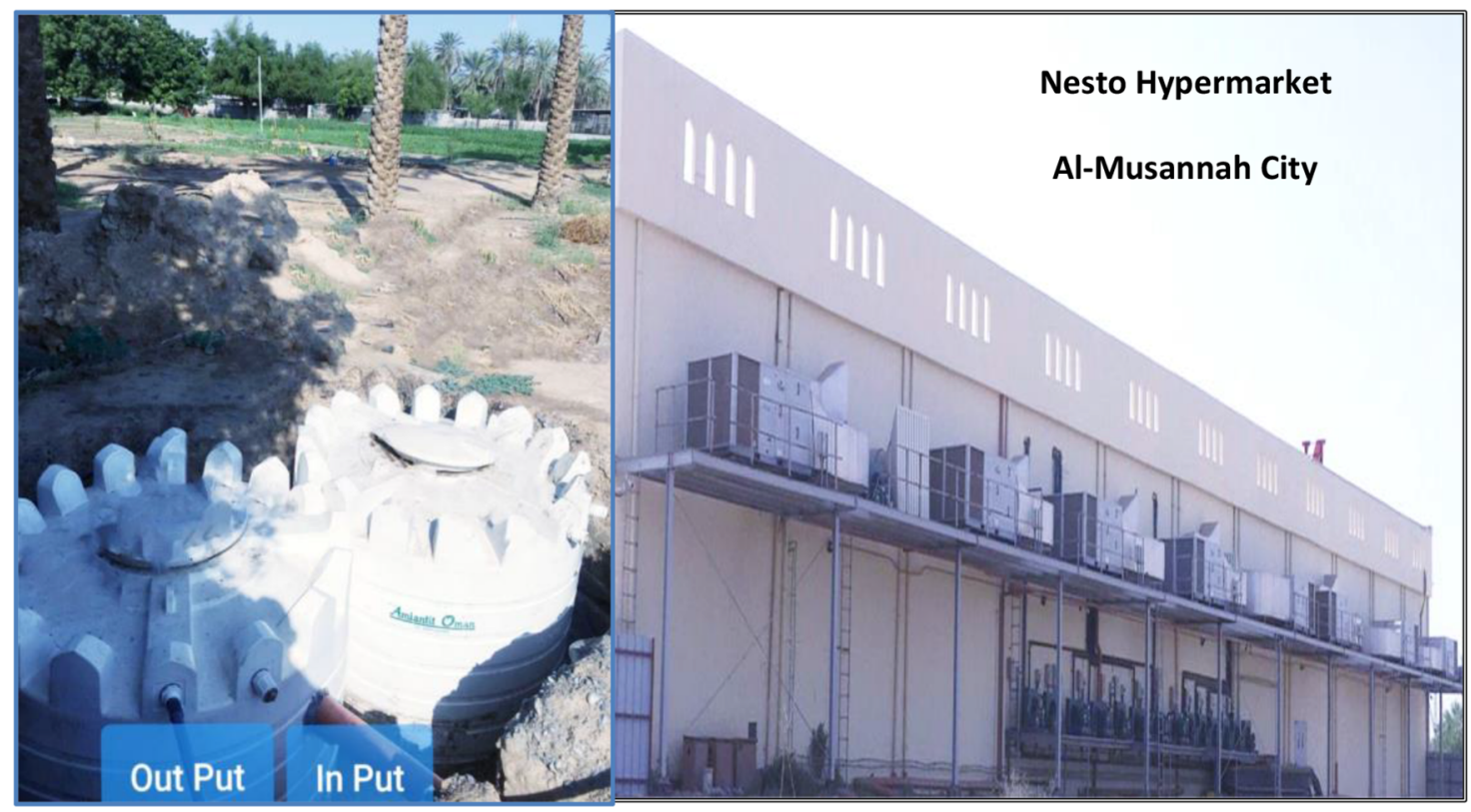

Fig. 13. Water collection system, plastic tanks and cooling units.

Table 2. Includes the collected byproduct water in many dates together with correlated information.

\begin{tabular}{lllllll}
\hline Date & $\begin{array}{l}\text { Duration } \\
\sim \mathrm{h}\end{array}$ & $\begin{array}{l}\text { Quantity } \\
* \text { Gallon } \\
8 \mathrm{AC}\end{array}$ & $\begin{array}{l}\text { Quantity } \\
\text { Liter }(\mathrm{L}) \\
8 \mathrm{AC}\end{array}$ & $\begin{array}{l}\text { Water Rate L/h } \\
\text { One AC }\end{array}$ & $\begin{array}{l}\text { RH\% Mean } \\
\text { Value }\end{array}$ & Air-Temp. ${ }^{\circ} \mathrm{C}$ \\
\hline $28-08-2020$ & 12.5 & $1200 \mathrm{G}$ & 4560 & 45.6 & 87 & 29 \\
$26-09-2020$ & 20 & $1200 \mathrm{G}$ & 4560 & 28.5 & 51 & 33 \\
$27-09-2020$ & $16 \mathrm{~h}$ & $1200 \mathrm{G}$ & 4560 & 35.6 & 66 & 37 \\
$18-10-2020$ & $19 \mathrm{~h}$ & 1200 & 4560 & 30 & 57 & 27 \\
Total & 67.5 & 4800 & 18240 & & & \\
\hline
\end{tabular}

*Gallon $\approx 3.8 \mathrm{~L}$.

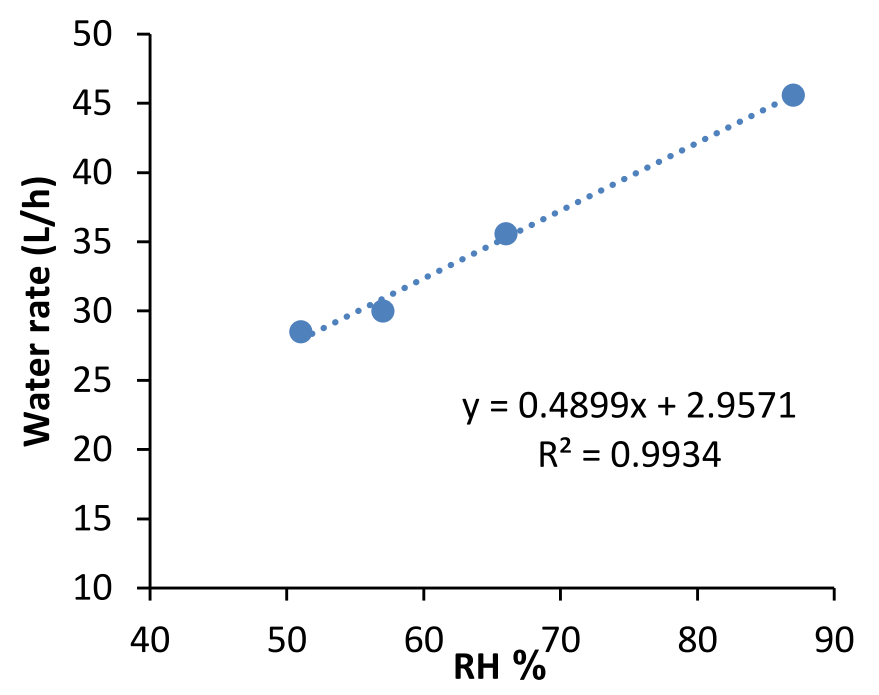

Fig. 14. Water rate as a function of $\mathrm{RH} \%$ mean value for one aircooling unit, Al-Musannah, Oman.
From the obtained curves in Figures 7 and 8, it can be straightforwardly concluded that generally all selected locations are characterized by high $\mathrm{RH} \%$, because they are coastal locations. Also, it is relatively easy to conclude that the $\mathrm{RH} \%$ increases as headed to the south of Oman, as the city of Dhalkut is located far south of Oman, as shown in Figure 3. The values of $\mathrm{RH} \%$ (Max., Mean, Min.) of Dhalkut are $89 \%, 76 \%$, and $60 \%$, respectively. Increase of $\mathrm{RH} \%$ values are probably due to the decreasing of the airtemperatures, which continues towards the south, as illustrated in Figure 9. This situation commonly causes to increase the $\mathrm{RH} \%$ as this factor is inversely proportional to the Ta. The Ta difference is too much between Sohar and Dhalhut, Sohar Ta mean value for 4 years $(2016-2019)$ is higher than Dhalhut by about $8^{\circ} \mathrm{C}$, so that the $\mathrm{RH} \%$ values of this location are much greater than all other selected coastal locations. This is because the city of Dhalkut is mountainous nature, which generally characterized by lower air-temperatures compared with the other cities of none-mountainous.

On the other hand, Sohar location showed the highest values of $\mathrm{RH} \%$ among the cities of Oman, north of Muscat, the capital of Oman, by about $250 \mathrm{~km}$. The mean values of 
Table 3. Characterizations of the byproduct tested water.

\begin{tabular}{|c|c|c|c|c|c|c|}
\hline \multirow[t]{2}{*}{ Parameter } & \multirow[t]{2}{*}{ Sampe-1 } & \multirow[t]{2}{*}{ Sampe-2 } & \multirow[t]{2}{*}{ Sampe-3 } & \multirow{2}{*}{$\begin{array}{l}\text { Mean value } \\
\text { of } 3 \text { samples }\end{array}$} & \multicolumn{2}{|c|}{ Omanian St. 8/2012 } \\
\hline & & & & & Quality level & Max \\
\hline Temperature $\left({ }^{\circ} \mathrm{C}\right)$ & 25.8 & 26.1 & 26.6 & 26.16 & $20-35$ & 40 \\
\hline $\mathrm{pH}$ & 6.94 & 6.82 & 6.79 & 6.85 & $6.5-8.5$ & 8.5 \\
\hline Electrical conductivity $(\mu \mathrm{S} / \mathrm{cm})$ & 38.8 & 39.2 & 38.9 & 38.97 & - & - \\
\hline TDS (Total Dissolved Solids) mg/L & 17.09 & 17.05 & 17.28 & 17.14 & $100-500$ & 500 \\
\hline Chloride $\mathrm{Cl}^{-1}$ & 0.6 & 0.4 & 1.2 & 0.73 & $<150$ & 150 \\
\hline Total hardness & 31.64 & 25.38 & 22.33 & 26.45 & $<200$ & 200 \\
\hline Calcium hardness & 15.6 & 14.3 & 13.5 & 14.47 & $37.5-75$ & 75 \\
\hline
\end{tabular}

Table 4. Includes the results of the bacterial test before and after solar disinfection.

\begin{tabular}{llll}
\hline Results before sunlight irradiation, & & \\
\hline MPN/100 ml & Sample 1 & Sample 2 & Sample 3 \\
Total plate count & Contaminated & Contaminated & Contaminated \\
Coliform & $<64$ & $<67$ & $<63$ \\
E-coli & $<41$ & $<42$ & $<40$ \\
Results after sunlight irradiation & & & \\
MPN/100 ml & Sample 1 & Sample 3 & Sample 3 \\
& $1 \mathrm{~h}, \sim 47{ }^{\circ} \mathrm{C}$ & $1.5 \mathrm{~h}, \sim 56{ }^{\circ} \mathrm{C}$ & $2 \mathrm{~h}, \sim 65{ }^{\circ} \mathrm{C}$ \\
Total plate count & Contaminated & Absent & Absent \\
Coliform & 60 & Absent & Absent \\
E-coli & 26 & Absent & Absent \\
\hline
\end{tabular}

the RH\% (Max., Mean, Min.) of Sohar location are $80 \%$, $65 \%$, and $47 \%$, respectively. The reason for that is because the fact that Sohar is a coastal Province and characterized by broad agricultural areas, where the process of plant transpiration is another essential factor in increasing the $\mathrm{RH} \%$ of any place.

The last part of the meteorological data analysis is to discuss the result of plotting the solar irradiation recorded in the station of Muscat International Airport, which is about $3 \mathrm{~km}$ far from the coast of Muscat. Figure 10 shows the monthly global distribution of G for 3 years (20172019) of Muscat Int. Airport location. The mean value peak of these 3 years at this station is in June, which is about $7300 \mathrm{Wh} / \mathrm{m}^{2}$. Figure 11 reveals the annual global mean values of $\mathrm{G}$ for the same period above. The result is an almost straight line with a negative slope of about $93 \mathrm{~W} / \mathrm{m}^{2} \mathrm{y}$. This case means that there is a little gradually descent in the global $G$ within the last three years. If this case is generalized on Omani weather, which can help to explain the decline of the air-temperatures through 2019 as seen in Figures 5 and 6 .

The obtained meteorological data were analyzed as an introduction taking advantage of the humidity that is already available in a high level in coastal areas with the presence of high intensity of solar radiation for water production.

\subsection{Water collection results analysis}

From Table 2, the water rate means for four runs of water collection is about $18240 \mathrm{~L}$ in $67.5 \mathrm{~h}$ by eight air-cooling units with a power rate of about $21.73 \mathrm{~kW}$, thus, the rate of water collection from one unit is approximately $34 \mathrm{~L} / \mathrm{h}$, when the mean value of $\mathrm{RH} \%$ of the four runs is about $65 \%$. This $\mathrm{RH} \%$ represents nearly the mean value of $\mathrm{RH} \%$ of the eight studied locations from Musandam in the far north of Oman to Dhalkut in the far south of Oman as shown in Figure 3 . The case of water collection from the mentioned Hypermarket for four days can be generalized to be valid for one year as follows:

$$
\text { Quantity of ware per hour }=\frac{18240 \mathrm{~L}}{67.5 \mathrm{~h}} \approx 270 \mathrm{~L} / \mathrm{h}
$$

Number of hours per year $=\frac{24 \mathrm{~h}}{\text { day }} \times \frac{365 \text { day }}{\text { year }}=8760 \mathrm{~h} /$ year

$\therefore$ The quantity of water per year

$$
=\frac{270 \mathrm{~L}}{h} \times \frac{8760 \mathrm{~h}}{\text { year }} \approx 2365200 \mathrm{~L} / \text { year } \approx 2365 \mathrm{~m}^{3} / \text { year }
$$


The winter season of Oman is about four months (Nov., Sept., Jan., and Feb.) in most Omani terriers. That is about $33 \%$ of the year period. Let assume the working cooling time of the used air-cooling units in the winter season is a half day per day, so the losing gained water during the winter season of Oman is about $17 \%$. For more reality, this percent can be considered $20 \%$. Hence the Net Annual Rate of accumulated water from the used cooling system in the present article is approximately:

$$
\begin{aligned}
\text { Net Annual Rate } & =2365 \mathrm{~m}^{3} / \mathrm{y}-(0.2)\left(2365 \mathrm{~m}^{3} / \mathrm{y}\right) \\
& \approx 1892 \mathrm{~m}^{3} / \mathrm{y}
\end{aligned}
$$

This annual net amount of water per year is great to be exploited as a byproduct, which practically free of charge from one Hypermarket nearby the coast in Oman. Thus, we can imagine how much quantity of water will be collected if the case is globalized at the state level.

From Figure 14, it seems that the relation between the rate of water collection and $\mathrm{RH} \%$ values is nearly a straight-line relationship:

$$
y=m \quad x+c
$$

where $y$ is the collected water rate $(\mathrm{WR})(\mathrm{L} / \mathrm{h}), \mathrm{m}(\mathrm{L} / \mathrm{h})$ is the slope of the straight line, $x$ is the $\mathrm{RH}$, and $c$ is constant. The slope of the straight line of Figure 14 is about $0.489 \mathrm{~L} / \mathrm{h}, \mathrm{c}$ is 2.957 , and $\mathrm{R}^{2}$ of the straight line is 0.993 , so the equation of the gained water rate is:

$$
\mathrm{WR}=0.489 \mathrm{RH}+2.957 .
$$

The preceding discussed case is due to one air-cooling unit with the mentioned specification in Table 1 . This condition can be generalized to applied for many aircooling units as follows:

$$
\mathrm{WR}_{\mathrm{n}}=n(0.489 \mathrm{RH}+2.957)
$$

where $\mathrm{WR}_{n}$ refers to the water rate at $n$ number of aircooling units at the same specification mention in Table 1.

The byproduct gained water has been used for irrigation of many types of trees, such as date palms, citrus, and mango, of about 100 trees in an orchard nearby the Nesto Hypermarket in Al-Musannah. The daily collected water is more than enough to irrigate this number of trees. This idea is amazing if it is generalized in Oman and elsewhere that have similar environment to gain the benefit of using this free of charge byproduct water. According to the annual estimated byproduct water rate $\left(1892 \mathrm{~m}^{3} / \mathrm{y}\right)$, and if each tree needs about $300 \mathrm{~L}$ a week on average throughout the year, especially if the orchard is near the coat of the sea. So, the total number of irrigated trees per year will be about 130 .

\subsection{Chemical analysis, physical test, and bacterial test analysis}

The results recorded in Table 3 refers that the collected water is almost neutral with a $\mathrm{pH}$ of about seven at the mentioned temperature in the table. Also, the electrical conductivity and the TDS are very low in compression with Omani drinking water standard. Therefore, all these parameters assure that the water is almost pure. Table 4 includes the results of bacterial tests before and after solar disinfection. The conclusion about these findings is that the water is already contaminated by some bacteria. This is quite expected result, because naturally there are plenty types of bacteria in the moisture of the atmosphere. Also, the information of Table 4 refers that the existing bacteria can be inactivated by solar energy at a temperature of about $56^{\circ} \mathrm{C}$ and higher. The exposure times were $1,1.5$, and $2 \mathrm{~h}$ in sun day $(08 / 11 / 2020)$, the associated temperatures were about 47,56 , and $65^{\circ} \mathrm{C}$, respectively.

In addition, the duplicate bacterial test on the samples that previously disinfected by solar energy showed negative results. That is superb to prove that solar disinfection method could be used to disinfect the contaminated water by bacteria forever, if it maintains sealed after solar disinfection, when of the water temperature reaches about $60^{\circ} \mathrm{C}$ and higher. The authors recommend that the temperature of the contaminated water must reach in the range of $60-65^{\circ} \mathrm{C}$ to guarantee completion of the disinfection by solar energy, and then sealing the product. This process can be conducted by filling transparent glass bottles with bacterial contaminated water and expose them to sunlight by using a wooden box with glass front side that designed for solar disinfection.

In conclusion and generally, the gained water from aircooling units in humid areas is nearly pure with a certain amount of bacteria that can be killed by any adopted disinfection methods, or by solar energy, to be ready for various uses.

\subsection{General remarks}

From the analysis results of the meteorological data in Oman, the studied of water collection from air-cooling units, and the feedback of the chemical, physical, and bacterial tests, the following remarks can be concise:

- The high-level of the relative humidity of the coast of Oman can be looked upon as a permanently suspended source for water production, that is due to the presence of the high solar radiation and the sea. This case is valid for all similar geography zones worldwide.

- The $\mathrm{RH} \%$ on the coast of Oman is high during the most days of the year as proved in the present article.

- The solar radiation of Oman is high enough to maintain the $\mathrm{RH} \%$ at a high level throughout the days of the year.

- The quantity of the gained water as a byproduct of aircooling units is massive, if measured at the national level.

- The collected water from air-cooling systems can help to augment water security of Oman.

- This immense byproduct water must be saved because an enormous electrical energy is already spent to run the used air-cooling units, and the country needs to save any drop of water, not to lose plenty of byproduct water. It is unwise to do so.

- The water can be exploited in many domestic applications. Also, it indeed can be used in the irrigation process in normal and horizontal farming. Also, it can be converted into drinking water after filtration, adding some required elements according to the adopted standard level of drinking water, and disinfection process. 
- The gained water can be utilized for hydrogen production as it is almost freshwater with a $\mathrm{pH}$ of nearly neutral (about 7). So, it can be converted into energy carrier fuel instead of fossil ones.

\section{Conclusions}

In the present article, three parts were investigated and discussed; these are Omani meteorological data analysis in term of (humidity, solar intensity, and air-temperatures), collection of releasing byproduct water from air-cooling units to specify the potential of water production, and followed by chemical, physical, bacterial tests. The new findings of the research work can be summarized as follows:

- The meteorological data analysis proved that the $\mathrm{RH} \%$ increases toward the south of Oman, where the airtemperatures decrease toward the south as well. Meanwhile, the study confirmed that the leading cause of the high level of $\mathrm{RH} \%$ is the high solar irradiation of the GGC states.

- The analysis also revealed that the general $\mathrm{RH} \%$ mean value across the coast of Oman for many years is about $68 \%$ and confirms the necessity of paying much attention to exploit this factor to produce almost pure water from atmospheric moisture.

- It is found that the amount of water byproduct coming out of air-conditioning systems is massive and should not be ignored to augment water security of any country. Annually, it is approximately $1892 \mathrm{~m}^{3} / \mathrm{y}$ on average from one Hypermarket near the coast in Oman. The quantity of accumulated water will be too great if the idea is generalized at the national level.

- The chemical and physical tests showed that the collected water is almost distilled water with a $\mathrm{pH}$ of around 6.85 . In addition, its TDS and EC are very low and could be classified as almost pure water, consequently.

- The bacterial examination proved the presence of some bacteria, which can be inactivated by solar energy.

- The significant finding of this article is a humanitarian message to focus on the production of life matter from atmospheric moisture, especially in the coastal zones that received high and reasonable solar energy.

The authors would like to thank Mr. Altif Mohamed of Mahadha Water Natural Factory, Al-Buraimi Provence-Oman for his kind help to carryout the physical, chemical, and bacterial tests in their laboratory.

\section{References}

1. M. Bhargva, A. Yadav, Productivity augmentation of singleslope solar still using evacuated tubes, heat exchanger, internal reflectors and external condenser, Energy Sources, Part A Recover. Util. Environ. Eff. 00, 1-21 (2019)

2. S.J.P. Gnanaraj, V. Velmurugan, An experimental investigation to optimize the production of single and stepped basin solar stills - a Taguchi approach, Energy Sources, Part A Recover. Util. Environ. Eff. 00, 1-24 (2020)

3. A.S. Al Siyabi, N. Hakro, Green economy and sustainable development in the sultanate of Oman, J. Student Res. 00, $1-17$ (2020)

4. H.A. Kazem, Renewable energy in Oman: status and future prospects, Renew. Sustain. Energy Rev. 15, 3465-3469 (2011)

5. S. Fragaszy, R. Mcdonnell, Oasis At a Crossroads: Agriculture and Groundwater in Liwa, United Arab Emirates 15 (2016)

6. T. Al-Awadhi, S. Mansour, Spatial assessment of water quantity stress in sultanate of Oman provinces: a GIS based analysis of water resources variability, J. Geogr. Inf. Syst. 07, 565-578 (2015)

7. M.I. Hussain, A. Muscolo, M. Farooq, W. Ahmad, Sustainable use and management of non-conventional water resources for rehabilitation of marginal lands in arid and semiarid environments, Agric. Water Manag. 221, 462-476 (2019)

8. M.T. Chaichan, H.A. Kazem, Water solar distiller productivity enhancement using concentrating solar water heater and phase change material (PCM), Case Stud. Therm. Eng. 5, 151-159 (2015)

9. H. Mousa, J. Naser, A.M. Gujarathi, S. Al-Sawafi, Experimental study and analysis of solar still desalination using phase change materials, J. Energy Storage 26, 1-5 (2019)

10. G.F.L. Al-Doori, I.S. Moosa, A.A.M. Saleh, Enhanced productivity of double-slope solar still using local rocks, Int. J. Smart Grid Clean Energy 8, 307-312 (2019)

11. I.S. Moosa, H.A. Kazem, Review of basic renewable energy in GCC countries: current status and future vision, Int. J. Comput. Appl. Sci. 6, 397-406 (2019)

12. I.S. Moosa, B.B. Maqableh, N. Alattar, Production of fresh water from drain-water released from cooling air-conditioning systems: experimental and analysis studies, Int. J. Comput. Appl. Sci. 5, 350-355 (2018)

13. I.S. Moosa, L.M.R. Al-iessi, H.A. Kazem, Freshwater production and solar disinfection of water released from the air-conditioning cooling system: an experimental investigation 9, 1-10 (2020)

14. H.M.S. Al-Maamary, H.A. Kazem, M.T. Chaichan, Climate change: The game changer in the Gulf Cooperation Council Region, Renew. Sustain. Energy Rev. 76, 555-576 (2017)

Cite this article as: Iessa Sabble Moosa, Hussien A. Kazem, Humaid Al-Badi, Ahmed Said Al-Hashimi, Evaluation and analysis of freshwater from atmospheric moisture as byproduct of air-cooling units in Oman, Renew. Energy Environ. Sustain. 6, 19 (2021) 